
.

\title{
The American Suffrage Movement and the Novels of Marietta Holley and Elia Peattie as a means of Cultural Lobbying
}

\section{Emine Geçgil}

To cite this article: Emine Geçgil (2018) The American Suffrage Movement and the Novels of Marietta Holley and Elia Peattie as a means of Cultural Lobbying, Women's Writing, 25:3, 379-400, DOI: $10.1080 / 09699082.2018 .1473021$

To link to this article: https://doi.org/10.1080/09699082.2018.1473021

曲 Published online: 29 May 2018.

Submit your article to this journal $\widetilde{ }$

Џ Article views: 60

View Crossmark data $\complement$ 


\title{
THE AMERICAN SUFFRAGE MOVEMENT AND THE
} NOVELS OF MARIETTAA HOLLEY AND ELIA PEATTIE AS A MEANS OF CULTURAL LOBBYING

\author{
Emine Geçgil \\ School of English Language, Bilkent University, Ankara, Turkey
}

\begin{abstract}
Women's literary activity during the first two decades of the twentieth century, fuelled by the progressive spirit, served as a form of cultural lobbying through which they could articulate social and political problems and propose solutions. This article focuses on the struggle that enfranchised women by examining two long-forgotten suffrage novels, written in a period when grassroots activism, suffrage parades and house-to-house canvassing were a means of propaganda: Marietta Holley's Samantha on the Woman Question (1913) and Elia Peattie's The Precipice (1914). With her use of satire, Holley familiarizes her middle-class audience with women's suffrage and politics. By presenting the plight of different women in a vernacular style, Holley addresses the older generation of anti-suffragist women, illuminating how countless unfortunate women are oppressed by a political system that does not acknowledge their presence. On the other hand, in The Precipice, Elia Peattie appeals to the younger generation of New Women, portraying the life of a twentieth-century social reformer, who tries to balance her career as a municipal housekeeper with the traditional roles and values of her day. The article argues that both novels functioned as catalysts to bring about social change at a time when, on the federal level at least, women still could not vote or hold an elected office. Thus, even before women were enfranchised, these novels influenced the beliefs and opinions of female audiences, for whom reading fiction was a favourable pastime. Without marginalizing female protagonists or blatantly alienating readers by transgressing socially accepted gender norms, these authors were able to find a middle ground, successfully creating role models who try to change society from within. By rendering the New Woman unthreatening, they challenged the ideology of separate spheres and prepared the public for the great changes ahead.
\end{abstract}

During the Progressive Era, a widespread concern over social justice unavoidably shaped American politics. Although progressive women played a prominent role in the regulatory policies enacted, they remained peripheral to the progressive movement as they had not attained their political rights-in particular, the right to vote. By virtue of their domestic roles as housekeepers and 
nurturers, they served as municipal housekeepers, ${ }^{1}$ moral guardians ${ }^{2}$ and labour agitators. They required the suffrage, however, in order to become active participants and decision-makers in American political life, and to become far more visible in the public sphere. Only in this way would the transition from True Womanhood to New Womanhood be complete.

This article focuses on the struggle that enfranchised American women by examining two suffrage novels: Marietta Holley's Samantha on the Woman Question (1913) and Elia Peattie's The Precipice (1914). ${ }^{3}$ Both novels shed light on an eventful episode in American women's history, when much of the activism took place in the form of lobbying, suffrage parades and house-to-house canvassing. Both novelists allude to the real events that took place at the time they were written to clarify their goals. However, their styles as novelists are different. Where Holley embraces folksy humour to make satiric points, Peattie adopts the more conventional style of a romantic novelist. With her use of satire, Holley familiarizes her middle-class audience with women's suffrage and politics through Samantha's trip to Washington, DC. On the other hand, in The Precipice, Peattie appeals to the younger generation of New Women, portraying the life of a twentiethcentury social reformer, who tries to balance her career as a municipal housekeeper with the traditional roles and values of her day. Both novels take a mainstream, middle-class, progressive stance. While Samantha on the Woman Question exposes the plight of uneducated rural women who are deprived of their political rights, The Precipice depicts the modern and purposeful woman as she fights for social change and legal reform, specifically in the realm of suffrage. Both novels disseminated pro-suffrage arguments, serving as vehicles to bring about social change, and inviting middle-class audiences to participate in the suffrage movement without transgressing socially accepted gender boundaries.

Undoubtedly, the transition from True Woman to New Woman was facilitated by suffrage organizations. The National American Woman Suffrage Association (NAWSA) was the most important suffrage organization in the United States. It was established in 1890 through the merger of two rival suffrage societies: the National Woman Suffrage Association and the American Woman Suffrage Association. ${ }^{4}$ Under the leadership of Susan B. Anthony, the aim of the NAWSA was to welcome all women-despite their differences-to work for the cause to enfranchise women. While the NAWSA continued to lobby for both statewide enfranchisement and a national amendment to the US constitution, ${ }^{5}$ Harriot Stanton Blatch, Alice Paul and Lucy Burns introduced the militancy of the British suffragettes to the American suffrage movement. ${ }^{6}$ They founded the Congressional Committee, an auxiliary to the NAWSA, as a platform to engage in mild militancy in support of a national amendment. They organized a suffrage parade in March 1913, the day before the inauguration of Woodrow Wilson as 
president. The event became even more sensational when a large crowd of onlookers assaulted the marchers, and the police did little to intervene. ${ }^{7}$ Nevertheless, the event succeeded in reintroducing the suffrage amendment to the House of Representatives, focusing national attention on the cause.

Women's literary activity, fuelled by the progressive spirit of the era, served as a form of cultural lobbying through which they could articulate social and political problems, and propose solutions. Despite all the ideological and methodological differences, countless women writers contributed to the suffrage movement by writing fiction that targeted white, Protestant, middleclass audiences. A prominent suffragist and the co-founder of Virginia's Equal Suffrage League (with Ellen Glasgow), Mary Johnston (1870-1936), took an active part in parades and addressed state legislatures to promote the cause. Her novel Hagar (1910) exposes the tensions between the southern lady and the New Woman. ${ }^{8}$ In an attempt to promote California's suffrage campaign, Gertrude Atherton (1857-1948), a well-known woman novelist, wrote both fiction and non-fiction to support the cause. Her novel Julia France and Her Times (1912) chronicles the life of Julia France, a beautiful American woman of the high elite circles, who joins the Woman's Social and Political Union in the United Kingdom to escape from marriage. Similarly, Elizabeth Robins (1862-1952), an actress and novelist, was drawn into the British suffrage movement while residing in England, and her bestknown play, Votes for Women! (1907), the first suffrage drama, was subsequently turned into a novel, The Convert (1907). This became inspirational for the militant suffrage campaigners in the United States, who were disturbed by the moderate tactics performed by the NAWSA. The novel served as a propaganda tool in both labour and suffrage movements as it evoked cross-class sisterhood, bringing elite women and working-class women together. Undoubtedly, the first two decades of the twentieth century witnessed many other writers whose novels aimed to educate their readers in the realm of suffrage, to increase their enthusiasm, and to publicize particular state campaigns throughout the country. These novels were so influential that they became instrumental in shaping the ideology of their readers, and thereby helped to bring change.

\section{Marietta Holley and the women's suffrage movement}

Marietta Holley was a courageous woman writer who took up the male enterprise of satire, which was considered to be a political and socially "dangerous" literary form for women in the nineteenth century. ${ }^{9}$ In 1873, she published the satiric work My Opinions and Betsy Bobbet's under the "non-threatening" pseudonym "Josiah Allen's Wife" ${ }^{10}$ In her own words, she wrote the novel because "[t]he great subject of Wimmen's Rites kept a goarin' me, and a voice kept a sayin' inside of me, 'Josiah Allen's Wife, write a book givin' 
your views on the great subject of Wimmen's Rites". ${ }^{11}$ With My Opinions and Betsy Bobbet's, Holley launched her "Samantha" series, which portrayed the adventures of the Allens, including Samantha, who leaves her fictional town of Jonesville to raise awareness about a social injustice. The Samantha series was so popular at the time the books were published that they sold millions of copies in the United States. ${ }^{12}$ Holley, through the character of Samantha, criticizes Mormon polygamy in The Lament of the Mormon Wife (1880), while Sweet Cicely: Josiah Allen as a Politician (1885) is a temperance novel portraying the plight of women suffering from drunken husbands and fathers. ${ }^{13}$ With Samantha at Saratoga (1887), she focuses on dress reform, whereas Samantha among the Brethren (1890) calls for church reform. ${ }^{14}$ Samantha on the Race Problem (1892) addresses the white-slave traffic, American imperialism, xenophobia and race antagonism, while Samantha at the World's Fair (1893), Samantha in Europe (1896), Samantha at the St. Louis Exposition (1904) and Around the World with Josiah Allen's Wife (1905) familiarize the late Victorian True Woman with the outside world. ${ }^{15}$ With Samantha on Children's Rights (1909), ${ }^{16}$ Holley writes about children whose mothers need the ballot in order to protect them from harsh labour conditions, and to enact age-of-consent laws, ${ }^{17}$ and with Samantha at Coney Island and a Thousand Other Islands (1911), she continues educating her female readers on the most crucial social issues of her day, using humour as an indispensable rhetorical weapon. ${ }^{18}$ By the time Holley wrote Samantha on the Woman Question (1913) and Josiah Allen on the Woman Question (1914), ${ }^{19}$ she had replaced her pseudonym with her real authorial identity. As one biographer suggests, she did not want to hide behind "Josiah Allen's Wife" any longer, as she believed in the power of addressing a new generation of feminists directly. ${ }^{20}$

Jane Curry, who comprehensively studied how Marietta Holley used humour and satire to discuss and influence issues of gender equality, maintains that the nineteenth-century tradition of American humour fell into three categories: down east, southwest and literary comedians. The vernacular style was critical to all three categories:

Vernacular or dialect humor was rendered in the language of the common person who eschewed the lofty syntax and vocabulary of standard English in favor of more familiar, down-to-earth idioms, generally conveyed through creative misspellings, extensive homey metaphors, and the insights of the wise innocent. These heroes and heroines were often uneducated, but were blessed with healthy doses of "horse sense" and "mother-wit." They applied their observations of life $[\ldots]$ to local, national, and even international topics. ${ }^{21}$

Inspired by literary comedians such as Artemus Ward and Bill Arp, Marietta Holley adopted the dialect of rural New York State, ${ }^{22}$ devising proverbs and maxims spiced with homespun phrases. ${ }^{23}$ Employing the tradition of 
Yankee humour, which had already been established before the Civil War, Holley also added malapropisms, which the readers of her time found comedic. $^{24}$ Written in 1913, Samantha on the Woman Question focuses on women's rights and suffrage in particular. ${ }^{25}$

Krista Cowman, in her article "Doing Something Silly", contends that humour was a political tactic used by suffragettes in Britain during their campaign in 1903-14, and these suffragettes alleviated the stresses of the political campaign "by deliberately adopting 'silly' behaviours as a counterpoint to over-formal, male dominated [...] politics". ${ }^{26}$ Unlike women novelists who deployed sentimental tropes to disseminate their progressive causes, Holley, as a prominent suffragist writer, used humour and satire as a novelistic strategy to critique social and political injustices, and, just as Cowman suggests, created female characters who adopt "silly" behaviours while asking for the right to vote. ${ }^{27}$ This article analyses the propaganda value of Samantha on the Woman Question as a social novel which informs readers in a non-threatening way why female enfranchisement is necessary. It exonerates the American women's suffrage movement in the patriarchal public eye, while delicately refuting the anti-suffrage arguments of the president, senators and other prominent American social figures.

Holley's overall aim is to portray the plight of women across the nation, and how they are, in general, deprived of their social, legal, marital, political and economic rights. Holley does not portray Samantha as a suffering woman pursuing her own rights. Instead, she is an ambassador for her friend Serepta Pester, who "wanted the Whiskey Ring destroyed and her rights, and she wanted 'em both inside of two weeks" (4). Holley humorously narrates how women are deprived of their rights and bodily integrity as disenfranchised individuals: daughters are trapped in prostitution due to drunken fathers and brothers and the Whiskey Ring (5); widowed and unmarried women suffer from tax grievances due to man-made laws (5); mothers are left without children as fathers are granted custody and can easily give them away without the mother's consent (6); husbands acquire their wives' property on marriage due to the doctrine of coverture (8); "a woman can't testify in court, in any matter that is of mutual interest to husband and wife" (12); in the courts, women are tried and punished more severely than men "by the law [they have] no hand in making" (14); and men can beat their wives, and "the law of the United States don't approve of a man's whippin' his wife enough to endanger her life" (8). It is also implied that a man can legally beat his wife if she refuses sexual intercourse. Holley also criticizes Roosevelt's theory of race suicide by proclaiming: "Some men do git real wrought up about [race suicide] and want everybody to have all the children they can, jest as fast as they can, though wimmen don't all feel so" (10). She conveys through the use of satire that it has been 
[...] the boast of our American law that it takes care of wimmen. It took care of her. It held her in its strong protectin' grasp so tight that the only way she could slip out of it wuz to drop into the grave [...] Then it leggo. (7)

In the course of her criticism, Holley makes occasional references to important figures such as Susan B. Anthony and presidents Taft and Wilson, and to key suffrage events, including the 1894 New York State Suffrage Campaign, the great suffrage parade of 1913, and the militant activities of British suffragettes. She reveres and commemorates Susan B. Anthony, who died in 1906, observing her contributions to the movement and remembering how she became a target of sarcasm for male suffragists and anti-suffragists: "Susan's memory is beloved and revered, and the contemptuous ridicule of the onthinkin' and ignorant only nourished the laurels the world lays on her tomb" (45). Encounters with politicians are common in almost all the Samantha books. In fact, Samantha regards it as a personal duty to warn politicians about social and political inequalities, and to make recommendations accordingly. ${ }^{28}$ In the novel, Samantha speaks to William Howard Taft, the twenty-seventh president of the United States and Wilson's predecessor, and decides that although Serepta "is justified [by the president] in askin' for her rights, and to have the [Liquor] Ring destroyed", Taft is "not the one to do them" (26). Holley then critiques his successor, President Wilson, and arrives at the same conclusion that "there are so many influences and hendrances planted like thorns in the cushion of that chair that a man, no matter how earnest he strives to do jestright, can't help bein' pricked by 'em and held back" (50).

The novel also makes occasional references to the 1894 New York Suffrage Campaign, when Susan B. Anthony planned "a house-to-house canvass to collect signatures on a mammoth woman suffrage petition". ${ }^{29}$ Alluding to this campaign, Samantha humorously explains why the women in her town could not sign the petition, which reveals that these women prioritized their domestic chores over suffrage, ${ }^{30}$ as they believed it was not worth their time. However, as Holley implies, such women ironically had the most to gain from political reform. Furthermore, Holley dramatizes the great suffrage parade of 1913, which occurred the day before Woodrow Wilson's inauguration, in an attempt to improve the image of the suffrage movement in American society. Despite the popular view that "a suffragist wuz a slatternly woman with uncombed locks, dangling shoe strings, and bloomers" (45), she observes that the suffragists in the parade were dressed decently in white and pink. She feels proud of the marchers and, through Samantha, Holley also praises the meticulous organization of suffrage activists and how their adeptness strengthens the movement. Through this suffrage parade, Holley also refutes the "cult of female frailty", an aspect of the nineteenth-century doctrine of True Womanhood, by stating: 
It wuz a burnin' hot day, and many who'd always argued that women hadn't strength enough to lift a paper ballot, had prophesied that woman wuz too delicately organized, too "fraguile" [...] to endure the strain of the long march in the torrid atmosphere. (58)

In a humorous way, she remarks that: "it wuz a surprise even to the marchers that of all the ambulances that kept alongside the Parade to pick up faint and swoonin' females, the only one occupied wuz by a man" (58). Holley also praises the efforts of the suffragists in a very patriotic way, underscoring the power of democracy. She persuades her readers to take a pro-suffrage stance because, unlike their militant British sisters:

[...] our American Suffragettes employ the gentle, convincin' arts of beauty and reason. Some as the quiet golden sunshine draws out the flowers and fruit from the cold bosom of the earth. Mindin' their own business, antagonizin' and troublin' no one, they march along and show to every beholder jest how earnest they be. (57)

This event, for Samantha, is clearly more than a parade. In fact, she characterizes it as: "Good men and good women, each fillin' their different spears in life, but banded together for the overthrow of evil, the uplift of the race" (59). The speeches and arguments made by women suffragists from different states are so convincing that Samantha wonders "how anybody can help bein' converted to this righteous cause" (47). She believes that women's enfranchisement will uplift them to their righteous place, with "other good citizens of the United States"-in other words, side by side with (white) male citizens (she explicitly refers to race throughout the text) (47). Her spirit is contagious, and she even partially converts her complacent relative Lorinda and her anti-suffragist husband Josiah.

Holley also examines the militancy of British suffragettes through the Creation Searching Society, which was established by the leading men of Jonesville "for the purpose of searchin' out and criticizin' the affairs of the world, an' so far as possible advisin' and correctin' the meanderin's an' wrongdoin's of the universe" (3). The society convenes to discuss what can be done to help Englishmen who suffer at the hands of suffragettes, and what precautions can be taken to prevent the movement from spreading to America. Using humour, Holley conveys their ideas and, ironically, the action unanimously taken is proposed by an Englishman:

[...] h'I propose if we can't do anything else that a card of sympathy be sent to hold Hengland from the Creation Searchin' Society of America, tellin' 'em 'ow our 'earts bleeds for the men's sufferin' and 'ardships in 'avin' to leave their hoccupations to beat and 'aul round and drive females to jails, and feed 'em with rubber hose through their noses to keep 'em from starvin' to death for what they call their principles. (188-89)

Here, Holley directly refers to the harsh treatment received by British suffragettes, including arrests and forced feeding. Even though she does not totally 
approve of their tactics, she empathizes with their militancy. However, she feels the need to differentiate between American and British suffrage campaigners. By saying that "there are no men so noble and generous as $[\ldots]$ American men" (57) and revering American manhood, she exonerates the movement in the public eye.

\section{Feminism versus anti-suffragism in Samantha on the Woman Question}

In Samantha on the Woman Question, Holley places Samantha on a mission to end women's legal inequality. She portrays her as an ardent feminist, but within limits. She is careful not to challenge, overtly at least, traditional gender roles or call into question Samantha's femininity, especially in terms of her domesticity. She defends feminist ideas through a feminized vernacular humour that relies on a "crackerbox philosopher's rural common sense". 31 Thus, she is able to avoid some of the more serious suffrage debates-such as that the vote would ruin American society by turning women into men -by bypassing them altogether. In the novel, Samantha's malapropisms are consequently more than just "being funny"-they are "an elucidation of social criticism" without the gravity of social criticism. ${ }^{32}$

For instance, Samantha uses the word "sect" instead of "sex", the women's "spear" rather than "sphere", and "Aunty" to mean the prefix "anti". As Curry maintains, by using the word "sect", Holley polarizes men and women, underscoring the fact that they are distinct groups. In this regard, using the word "sect" is a kind of othering. Likewise, by using the word "spear" for "sphere", she implies that the ideology of separate spheres can also be deployed as a weapon to bring about social change. ${ }^{33}$ Holley also calls female anti-suffragists "She Aunties". By playing with the term "anti" and replacing it with "Aunty", she exposes the hypocrisy of wealthy anti-suffrage women with political power. ${ }^{34}$ In the novel, Holley depicts Miss Vincent, who

[...] wuz a ardent She Aunty and very prominent in the public meetin's the She Auntys have to try to compel the Suffragists not to have public meetin's. They talk a good deal in public how onwomanly and immodest it is for wimmen to talk in public. And she wuz one of the foremost ones in tryin' to git up a school to teach wimmen civics, to prove that they mustn't ever have anything to do with civics. (20)

Holley's description of the "She Aunties" could just as easily describe contemporary anti-feminist, patriarchal women, such as the Republican lawyer, politician and "housewife" Phyllis Schlafly, who rose to prominence during the Equal Rights Amendment battle of the 1970s and 1980s. Thus, Holley's characterization of such women is timeless.

Holley's use of homely wisdom and dialect was precisely designed to win over audiences harbouring anti-suffragist sentiments. ${ }^{35}$ Receiving the same 
message from a young, liberated New Woman might have threatened the older generation of female readers. On the other hand, hearing the same message from an "uneducated", rural, "true" woman, with her "carefully crafted image of illiteracy and domesticity", ${ }^{36}$ was entirely non-threatening. Throughout the novel, Samantha defends her cause on two fronts: she targets women who oppose women's rights and male politicians who are unwilling to take the necessary steps to enfranchise women. Her relative, Lorinda, who hosts the Allens in Washington, DC, is a foil character whom Holley devised to criticize Samantha's "unwomanly" ideals. ${ }^{37}$ As Samantha narrates, having a rich husband and a comfortable life, Lorinda, like other middle-class anti-suffragist women, believes that women already have all the rights they need, and that voting would not solve, but would create, problems.

Holley also underscores how women are successful at municipal reform in those states where women could vote. Deriving strength from such prominent figures as Frances Willard, ${ }^{38}$ Jane Addams, ${ }^{39}$ and Theodore Roosevelt, she embraces "Home Protection"- the idea that American women need suffrage in order to preserve the home and motherhood. Taking refuge in this argument, Samantha tries to outwit Lorinda by asking:

Do you think [...] if educated, motherly, thoughtful wimmen helped make the laws so many little children would be allowed to toil in factories and mines, their tender shoulders bearin' the burden of constant labour that wears out the iron muscles of men? (16)

Samantha believes that when women have equal legal power, they will be better wives and mothers because, with the help of the ballot, they will open schools to teach young girls how to keep healthy, comfortable homes and make themselves capable wives and mothers.

In Samantha on the Woman Question, Holley consistently refutes anti-suffragist sentiments during her encounters with senators. Senator A says: "Wimmen are the loveliest, most angelic creatures that ever walked the earth; they are prefect, flawless, like snow and roses" (28). He also maintains that "these angelic angels of our homes are too ethereal, too dainty to mingle with rude crowds" (29). His rhetoric exemplifies the patriarchal and paternalistic anti-suffrage arguments of the time, which posited that women should be in the home while men "took care" of business in the public sphere. This genteel tradition juvenilized women, deeming them sacred while undermining their existence, importance and intelligence. Not surprisingly, Samantha skewers the Senator by saying: "you call wimmen angels, and you don't give 'em the rights of the lowest beasts that crawl on the earth" (30). Despite sympathizing with the plight of women, the Senator compares the situation to slavery. Just like slave masters who could see the injustice of the "peculiar institution" but could not support change because the "old 
chains of Custom bound them", politicians, the Senator believes, are aware of the injustices suffered by women but cannot take action because their hands are tied by social customs (32).

Samantha also refutes the Senator's statement that: "the soft gentle brains of females are unfitted for the deep hard problems men have to grapple with. They are too doll-like, too angelically and sweetly frivolous" (33). This argument replicates those found in Molly Eliot Seawell's anti-suffragist essay "On the Absence of Creative Faculty in Women" (1891), which was ironically written by an intellectual woman. ${ }^{40}$ Samantha, however, provides readers with examples of prominent women who contributed to humanity. ${ }^{41}$ The Senator's claim that if these women were so important they would be represented in the Hall of Fame for Great Americans in New York City is refuted by Samantha, who argues that it would be so "if women formed half the committee of selection" (34) — clearly, a searing criticism of such a prominent American institution.

While it is difficult to assess the impact that Samantha on the Woman Question made on suffrage, the Samantha novels in general were certainly good propaganda for the cause. Both Frances Willard and Susan B. Anthony were so aware of the propaganda value of Holley's novels that they invited her to their conventions to give a speech. ${ }^{42}$ When Samantha on the Woman Question was published in 1913, one-quarter of the states had already granted limited or full suffrage to women, and full enfranchisement for all American women came seven years later with the ratification of the Nineteenth Amendment. Appealing to the readers of her generation and the new generation of feminists, Holley refuted sentimental, pro-natalist arguments against women's rights, and tried to prove, through Samantha's cogent arguments, that women would not lose their virtue if they received the right to vote. Clearly, by refuting the irrational opposition of anti-suffragists with humour and satire, she, at a minimum, familiarized all readers, pro and con, with the cause of women's suffrage.

\section{Women's suffrage, the settlement house movement and Elia Wilkinson Peattie}

Journalism was another area through which women writers expressed their ideas. Elia Wilkinson Peattie used her journalism to disseminate her reforming zeal while entertaining readers with narratives comprised of fact, fiction or a blend of both. Born in 1862 in Kalamazoo, Michigan, to a ninth-generation American family, Elia Wilkinson Peattie was raised in Chicago, where she attended school until sixth grade. She married Robert Peattie, a reporter from the Chicago Tribune, in 1883, and took up writing with her husband, becoming the newspaper's first "girl reporter". The couple moved to Omaha, Nebraska, in 1888 and started working for the Omaha World 
Herald, where Elia Peattie edited the women's page and wrote a weekly column. ${ }^{43}$ Portraying new women like herself, who felt torn between the tenets of True Womanhood-piety, purity, submissiveness and domesticity -and the ideals of New Womanhood-emancipation, equality and opportunity-Peattie brought a fresh approach to journalism by writing factual editorials, crafting short, fictionalized narratives that supported her causes, and personalizing the news through fictionalized sketches based on real events. ${ }^{44}$ Like her contemporaries, Peattie believed in the importance of collective action and became a grass-roots activist. Some of her achievements include the establishment of the Omaha Women's Club and later the Nebraska State Federation of Women's Clubs. As an ardent suffragist, she attended the national conference of the General Federation of Woman's Clubs in Philadelphia in 1894 to represent the Omaha Women's Club, sharing the stage with Susan B. Anthony. ${ }^{45}$ In so doing, she gained prominence among suffragists and was more able to make contact with the female middle-class readership. Through club work, Peattie became an ardent advocate and spokesperson for women's rights. In the last decade of the nineteenth century, she travelled extensively around Nebraska to gather material for her writing on social injustice, municipal housekeeping, alcoholism, the annexation of Cuba, the Wounded Knee massacre, women's role in the church and unmarried mothers. Around the same time, Peattie returned to Chicago and started working as a literary critic for the Chicago Tribune between 1896 and 1917, becoming a prominent figure on Chicago's flourishing literary scene. She became a member of the book club Fortnightly and the Little Room Literary Club, and served as a leader in the Chicago Women's Club. ${ }^{46}$

Peattie authored numerous novels and short stories. As a mother of four children, she successfully balanced her domestic life with her career as an author. Elia Peattie was such a prolific writer that she published novels, plays, short stories and poems, as well as countless editorials, columns and book reviews until 1917. Her work was published in prestigious journals including the Atlantic, Century and Harper's. Many of her stories were collected in anthologies, such as The Mountain Woman (1896) and The Shape of Fear and Other Ghostly Tales (1898). ${ }^{47}$ Her novels included The Edge of Things (1903); a series of children's books, Azalea: The Story of a Girl in the Blue Ridge Mountains (1912), Annie Laurie and Azalea (1913) and Azalea's Silver Web (1915); The Precipice (1914); and The Angel with a Broom (1915). ${ }^{48}$ Elia Peattie died at the age of 73, in 1935, in Wallingford, Vermont.

Between the mid nineteenth and the mid twentieth centuries, middle-class American writers and reformers often "downclassed" in the name of reform, adopting a lower-class status in order to engage with those whom they sought to help. While male reformers regarded downclassing as part of investigative 
sociology, female downclassers, like Jane Addams, lived in settlements where they abandoned their creature comforts for the betterment of the underprivileged, and regarded the experience as self-renewing social work. ${ }^{49}$ Elia Peattie's progressive novel The Precipice depicts the heroine's downclassing experience and her vital contact with impoverished mothers, fallen daughters and neglected children, much the same as Addams and other municipal reformers did. ${ }^{50}$ However, embedded within this work is commentary about the abuses and inequalities faced by disenfranchised women. ${ }^{51}$ Like its author, The Precipice embraces almost all the causes of the Progressive Era-especially women's suffrage-reiterating Peattie's convictions concerning municipal housekeeping. In the novel, the female protagonist, Kate Barrington, becomes a prominent social worker, who collaborates with Julia Lathrop and Jane Addams, both of whom recruit her to be the head of the Children's Protective League-a real organization established by Julia Lathrop. Kate devotes herself to her job, giving lectures throughout the country, and participates in events organized by the General Federation of Women's Clubs. Like many progressive women's social novels, The Precipice campaigns for a range of causes at the same time, from conservation to the elimination of vice, the plight of women workers to child abuse-in other words, numerous forms of municipal housekeeping within the settlement house movement, crowned by the cause of all causes: women's suffrage. In order to illustrate the urgency of women's enfranchisement, Peattie creates a progressive heroine, Kate Barrington, who prioritizes civic work over every other aspect of her life, including her love interest.

Although the suffrage movement seems peripheral in The Precipice, it in fact lies at the heart of the novel. At every turn, Peattie reminds readers of the necessity of enfranchisement, and underscores the fact that ordinary women's unhappiness and career women's restlessness are caused by disenfranchisement. In other words, through The Precipice, Peattie conveys that women in the city-educated or uneducated-suffer from the same inequalities and domestic burdens cast upon them as wives and mothers, which results from not being recognized legally and represented politically.

In The Precipice, Peattie regards urban society as an extended family, and provides her protagonist with an outlet-the corrupt city-in which to use her maternal powers. ${ }^{52}$ Thus, in the novel, domestic abilities, which were formerly restricted to the private household, are transferred to the public sphere, with the metaphor of the family uniting both halves of society. In the same way that Holley makes reference to Susan B. Anthony, Peattie reveres and pays tribute to Jane Addams, who maintained that the city was "a great home" which accommodated a "civic family":

[Jane Addams] was a woman with a genius for inclusiveness. She was the sister of all men. If a youth sinned, she asked herself if she could have played any part 
in the prevention of that sin had she had more awareness, more solicitude. It was she who had, more than others-though there was a great army of men and women of good will to sustain her-promulgated this idea of responsibility.

Peattie describes social workers, such as Kate, who downclass as "the Addams breed', and suggests that she is a saviour who is "getting at the roots of our disease, and it's partly because she's a woman" (97).

Without downplaying women's roles as wives and mothers, Peattie relocates the concept of "biology as destiny" to the public sphere, where she integrates domesticity with a civic career. ${ }^{53}$ Nevertheless, women like Kate still faced prejudice, malice and old-fashioned paternalistic rhetoric since, ultimately, they transgressed spheres and blurred social boundaries. Working with the impoverished, Kate becomes a more understanding and empathetic person, and her downclassing experiences have a healing effect on her soul. Social work brings meaning to her life:

I used to feel like a person walking in a mist. But it's different now. Everything has taken on a clear reality to me. I'm even beginning to understand that I myself am a reality and that my thoughts as well as my acts are entities. (44)

As Peattie posits, being a social reformer strengthens a woman and enables her to view life from a different perspective. Moreover, her work helps her to heal not only herself but also others:

If only women-all women-understood how to make true homes, there wouldn't be any need for people like us. We're only well-intentioned fools who go around putting plasters over the sores. We don't even reach down as far as the disease. (36)

Clearly, if women could get the vote, they would have more opportunity to reach the root of social problems since they would be participating in the law-making process.

As a New Woman, Kate believes that women need enfranchisement for spiritual reasons which anti-suffragists do not generally recognize. In the same vein as Holley in Samantha on the Woman Question, Peattie also mentions the common anti-suffrage arguments: that women should be kept as far away as possible from the dirty business of politics, and that anti-suffragist males are actually protecting women by not enfranchising them. However, Kate believes that

[...] women desired the ballot because it was a symbol as well as because it was an instrument and an argument. If it was to benefit the working woman in the same way in which it benefited the working man, by making individuality a thing to be considered; if it was to give the woman taxpayer certain rights which would put her on a par with the man taxpayer, a thousand times more it was to benefit all women by removing them from the class of the unconsidered, the superfluous, and the negligible. (47) 
At this point, Peattie uses the same argument as Holley, whose Samantha believed that enfranchisement would uplift women from the "unfit" class to that of the able-bodied, respected, decision-making citizen. Kate maintains that women's suffrage included potentiality, "and in potentiality is happiness" (47). As a social reformer, she is well aware that the arduous tasks which women perform to preserve the "great home" of America would be best served by the ballot. She believes that women were created with potential, and that they simply need opportunities to fulfil their potential. Just as liberty is regarded as an "ethic need of civilization" (48), enfranchisement, she deems, is necessary for women. Kate regards the ballot "as the best bulwark of liberty" (115), drawing attention to the fact that every woman requires it, regardless of education level or marital status, whether she is a rural housewife or an urban career woman. Although Kate is relatively independent, she still sees enfranchisement as an indispensable right, even for social reformers such as herself. Repeatedly, Peattie reminds her philanthropist readers (especially those in anti-suffragist women's clubs) of the necessity of enfranchisement, warning them that if they take a stand against women's suffrage, all the civic work they do to improve the lives of the underprivileged would ultimately be in vain:

You toil for deserted children, indigent mothers, for hospitals and asylums, starting movements which, when perfected, are absorbed by the city. What happens then to these benevolent enterprises? They are placed in the hands of politicians and perfunctorily administered. Your disinterested services are lost sight of; the politicians smile at the manner in which you have toiled and they have reaped. You see sink into uselessness, institutions, which, in the compassionate hands of women, would be the promoters of good through the generations. (116)

In common with Holley's Samantha on the Woman Question, Peattie depicts a suffrage parade (which we assume to be the Chicago Suffrage Parade of 2 May 1914) in detail, glorifying the women who came together for a righteous cause: revolution. Yet she also portrays the backlash against the suffrage parade through the sexist male characters she creates. David, the husband of Kate's friend, finds the suffrage parade "uproariously funny" (81), and Ray McCrea, Kate's old friend, is surprised when he learns that Kate was "in that mess", and calls it "the Amazon march" (83). Although Ray appreciates her warring spirit, he laments that he feels ashamed "to find [Kate] marching with the militant women" (89). Again as in Holley's case, Peattie differentiates between the American and British suffrage movements. While sympathizing with British suffragettes, Peattie also strategically reveres American manhood. She does not approve of "acid-throwing and window-breaking" (184). As she states: "for one thing, it doesn't seem to me quite logical, as the damage is inflicted on the property of persons who have nothing to do with the case" (185). 


\section{The New Woman in The Precipice}

In her column in the Omaha World Herald on 28 September 1895, Elia Peattie defines the New Woman:

The woman who took herself inertly, who rested as she was made, neither watering her mind with knowledge nor cultivating her body by exercise, is no more to be compared to the cultivated woman than the wild plums to the perfect product of the carefully tended orchard. ${ }^{54}$

It is out of this definition that Peattie creates her heroine Kate Barrington, the ideal New Woman, who opposes women's identification with men at all costs. Thus, initially, she does not accept Karl's proposal. Rejecting the belief that a woman's place is with her husband, Kate criticizes the earlier generation of women, who acted "cowardly", fearing conventions:

They had lacked the ability to utilize their powers of efficiency; had paid but feeble respect to their own ideals; had altogether measured themselves by too limited a standard. Failing wifely joy, they had too often regarded themselves as unsuccessful, and had apologized tacitly to the world for using their abilities in any direction save one. They had not permitted themselves that strong, clean, robust joy of developing their own powers for mere delight in the exercise of power. (47)

Throughout the novel, Kate is seeking independence: “I don't want to be protected. I mean I don't want to be made dependent; I don't want my interpretations of life at second-hand. I object to having life filter through anybody else to me" (146). Thus, she is looking for full partnership, without sacrificing intellectual compatibility, freedom or romance. As a New Woman, Kate wants to have it all, and demands "rights and privileges equal to those enjoyed by men" (189). Peattie allows Kate to proclaim her independence with her version of the "Declaration of Independence" on a precipice, during one of her mountain walks with Karl, the man she loves:

I declare my freedom! [...] Freedom to think my own thoughts, preach my own creeds, do my own work, and make the sacrifices of my own choosing. I declare that I will have no master and no mistress, no slave and no neophyte, but that I will strive to preserve my own personality and to help all of my brothers and sisters, the world over, to preserve theirs. I declare that I will let no superstition or prejudice set limits to my good will, my influence, or my ambition! (190)

Peattie's use of the precipice for her declaration of independence is not coincidental. ${ }^{55}$ Neither is the novel's title. Here, the precipice on which Kate stands as a strong New Woman metaphorically refers to the fact that being an independent woman is like standing on the edge. Although Karl implies that it may be fatal, Kate claims she will not fall, and if other women fall, this would be due to fear, "the most subtle of foes" (190).

Kate Barrington also influences the male protagonist she loves. Karl is a benevolent magnate of an industrial town who fosters self-respect among 
his employees, which does not exist in other industrial settings. By matching Kate and Karl-a municipal mother and a civic father-Peattie renders significant the "spousal trait of sharing elements of the settlement worker social philosophy" ${ }^{56}$ However, as benevolent as he is, Karl bears traditional convictions, and Kate's ability to transform him comes into play at this point. The ending of the novel demonstrates how Karl, fearful of losing Kate forever, is converted:

Go your way, Kate. Go to your great undertaking. Go as my wife. I stay with my task. It may carry me farther and bring me more honour than we yet know. I shall go to you when I can: you must come to me-when you will. What more exhilarating? (217)

Here, Peattie revises the traditional marriage plot. ${ }^{57}$ While Kate is the New Woman, by the end of the novel, Karl Wander becomes the New Man. Their mutual partnership, as they rename marriage, sets an example for a new generation of feminists, and Kate remains "free and proud as the 'victory' of a sculptor's dream" (217). As Patrick Chura contends, Peattie is well aware that the complex needs of such a New Woman could only be met by a New Man. When he tells Kate that both can follow their own paths, Karl's public paternalism merges with Kate's public maternalism. ${ }^{58}$ Thus, The Precipice serves as a vital catalyst for social change. Kate becomes a successful role model for personal and professional independence, showing women that they can balance career and home, as long as they are not afraid of standing on the precipice.

\section{Conclusion}

Although progressive women were influential in reform movements, their efforts were limited since they did not have the right to vote. Women novelists of the time informed middle-class audiences about the necessity of women's enfranchisement, even as anti-suffragist arguments remained fashionable. Marietta Holley was a suffragist novelist who, with Samantha on the Woman Question, adopted a literary trope unexpected of women writers at the time. Through satire, she allowed her protagonist, Samantha Allen, to use her horse sense, homespun wisdom and carefully woven sarcasm to persuade older women to abandon "moth-eaten" arguments about women's suffrage. By refuting anti-suffragist arguments using humour, she exonerated the movement in the public eye and, with her novels, became an influential figure in women's suffrage.

On the other hand, Elia Peattie encouraged women to seek careers, fight against vice and corruption, and, above all, acquire the vote. In The Precipice, the progressive protagonist, Kate Barrington, served as a successful role model for younger generations of women. Without transgressing her traditional role as a woman and potential mother, Kate deconstructs the "biology as destiny" 
argument and finds new meaning in her life through municipal housekeeping and balance. Conveying her beliefs through Kate, Peattie underscores the necessity of female enfranchisement, making women's suffrage a central issue.

Both novels approach women's suffrage from a mainstream, white, middleclass, Protestant, progressive stantce, the former by supporting uneducated rural women who are deprived of their rights, and the latter by promoting the modern woman, who personally and professionally proclaims her independence. All in all, both novels advocated suffrage and served as vehicles to enact social change. Without threatening socially accepted gender norms, both novelists and protagonists called on middle-class audiences to participate in the suffrage movement.

\section{Notes}

1. The plight of women who were working under hard conditions attracted the attention of reform-minded middle-class women, who especially wanted to improve the lives of poor, white Protestant women by changing society from within. To this end, progressive reformers worked under the roof of many benevolent organizations. They endorsed legislative goals, sending petitions to Congress to address specific social issues. Women's clubs allowed them to confront problems in a socially acceptable manner that worked within the confines of American gender roles-namely, by using their positions as daughters, wives and mothers to carry out projects to improve the lives of other daughters, wives and mothers. Invoking their maternal duties to protect children and care for the poor, the women of the Progressive Era created a civic awakening, known as "municipal housekeeping".

2. "Moral guardian" is the term used for the progressive women who tried to eradicate the social ills of society such as alcohol, prostitution and delinquency in order to improve the well-being of the home and the nation. Women of the Progressive Era acted as moral guardians, campaigning against all the forces that corrupt American society.

3. Marietta Holley, Samantha on the Woman Question (New York: Fleming H. Revell, 1913); Elia Wilkinson Peattie, The Precipice: A Novel (New York: Houghton Mifflin, 1914). Subsequent references are to these editions and given parenthetically in the text.

4. Founded in 1869 by Elizabeth Cady Stanton (1815-1902) and Susan B. Anthony (1820-1906), the National Woman Suffrage Association opposed the ratification of the Fifteenth Amendment, which enfranchised African American males. It focused primarily on a national amendment to grant women the right to vote, and openly discussed controversial topics such as contraception and divorce. The American Woman Suffrage Association, on the other hand, which was founded in 1869 by Lucy Stone (1818-93) and her husband Henry Browne Blackwell (1825-1909), supported the Fifteenth Amendment and focused on state-based constitutional amendments, avoiding the controversial issues that the National Woman Suffrage Association supported. Without doubt, such differences in approach marked a 20 -year split in the women's suffrage movement, even delaying victory. 
5. Ellen Carol DuBois and Lynn Dumenil, Through Women's Eyes: An American History with Documents (Boston: Bedford/St. Martin's, 2005), p. 425. Women in Washington, California, Arizona, Kansas and Oregon were enfranchised between 1910 and 1912 as a result of successful campaigns held at the state level, whereas the failures in Ohio, Wisconsin and Michigan encouraged suffragists to focus on a constitutional amendment.

6. Harriot Stanton Blatch (1856-1940) was the daughter of Elizabeth Cady Stanton. She received her education in England and came to the United States full of ideas of suffrage and equality. Initially working with the Women's Trade Union League, she founded the Equality League of Self-Supporting Women as the political wing of the Women's Trade Union League, which was later renamed the Women's Political Union, with the goal of bringing together elite women and working-class women under the umbrella of suffrage. See Ellen Carol DuBois, ed., Woman Suffrage and Women's Rights (New York: New York UP, 1998), p. 192. Blatch organized and led the 1910 New York suffrage parade, as well as militant street protests. Likewise, Alice Paul (1885-1977) and Lucy Burns (1879-1966) were also educated in England. When they returned to the United States, they joined the NAWSA, but were disturbed by its acquiescence under Anna Howard Shaw.

7. See Marjorie Spruill Wheeler, ed., One Woman One Vote: Rediscovering the Woman Suffrage Movement (Troutdale, OR: NewSage, 1995), p. 278.

8. Mary Chapman and Angela Mills, Treacherous Texts: US Suffrage Literature, 1846-1946 (New Brunswick, NJ: Rutgers UP, 2011), p. 211.

9. Charlotte Templin, "Marietta Holley and Mark Twain: Cultural-Gender Politics and Literary Reputation", American Studies, 39.1 (1998): 75-91 (75). Templin suggests that in terms of style, Holley was likened to Mark Twain. Both Holley and Twain had the same publisher and the same illustrator, and were marketed in the same way, through subscription. Yet her male contemporary Mark Twain became one of the best-known literary figures in American history, while Marietta Holley remained in the shadows until she was rediscovered by 1970 s feminists.

10. Marietta Holley, My Opinions and Betsy Bobbet's (Hartford, CT: American, 1873). The novel centres on the clash of ideas between a caricatured manhunting spinster, Betsy Bobbet, and a practical rural woman, Samantha Allen (Josiah Allen's wife), who is a down-to-earth spokesperson for women's rights.

11. Holley, My Opinions, p. 12.

12. Margaret Wyman Langworthy, "Holley, Marietta", Notable American Women, 1607-1950: A Biographical Dictionary, ed. Edward T. James, Janet Wilson James, and Paul S. Boyer, vol. 1 (New York: Harvard UP, 1971), p. 203. In addition to the large sales, the popular success of the Samantha books was proven by the public readings, the successful dramatization by Neil Burgess, an American Vaudevillian comedian, and the demand from the publishers.

13. Marietta Holley, The Lament of the Mormon Wife (Hartford, CT: American, 1880); Sweet Cicely: Josiah Allen as a Politician (New York: Funk and Wagnalls, 1885).

14. Marietta Holley, Samantha at Saratoga (Philadelphia: Hubbard, 1887); Samantha among the Brethren (New York: Funk and Wagnalls, 1890).

15. Marietta Holley, Samantha on the Race Problem (New York: Dodd, Mead, 1892); Samantha at the World's Fair (New York: Funk and Wagnalls, 1893); Samantha in Europe (New York: Funk and Wagnalls, 1896); Samantha at 
the St. Louis Exposition (New York: G. W. Dillingham, 1904); Around the World with Josiah Allen's Wife (New York: G. W. Dillingham, 1905).

16. Marietta Holley, Samantha on Children's Rights (New York: G. W. Dillingham, 1909).

17. Jane Curry, Marietta Holley (New York: Twayne, 1996), p. 76.

18. Marietta Holley, Samantha at Coney Island and a Thousand Other Islands (New York: Christian Herald, 1911).

19. Marietta Holley, Josiah Allen on the Woman Question (New York: Fleming H. Revell, 1914).

20. Kate H. Winter, Marietta Holley: Life with Josiah Allen's Wife (Syracuse, NY: Syracuse UP, 2005), p. 145.

21. Curry, p. xiv.

22. Nancy Walker and Zita Dresner, eds., Redressing the Balance: American Women's Literary Humor from Colonial Times to the 1980s (Jackson: UP of Mississippi, 1988), p. 98.

23. Lara Hernandez Corkrey, "Marietta Holley, Alice Duer Miller, the Rhetoric of Suffrage Humor, and the Changing Notions of Womanhood 1848-1920", PhD thesis, U of Kansas, 2007, p. 101.

24. Langworthy, p. 203.

25. The novel portrays a period in the life of Samantha and Josiah Allen, who decide to leave their fictional town of Jonesville to attend an Allen family reunion in Washington, DC. Samantha has other plans as well, such as conveying her friend Serepta Pester's concerns about women's legal rights to Washington politicians, and seeing the great suffrage parade that will take place the day before Woodrow Wilson's inauguration. However, Samantha is disappointed by her encounters with politicians, thus she directs her attention and enthusiasm to the suffrage parade, where she shares her opinions and observations with readers. Samantha's DC mission ends when they return home, where the local anti-suffrage group, the Creation Searching Society, gathers to discuss the militancy of British suffragettes and what they can do to stop it from spreading to America. Samantha overhears suggestions proposed by male members of the society (including her husband Josiah), which range from killing off the whole female race to poisoning them (reminiscent of Jonathan Swift's satirical 1729 work A Modest Proposal), to exiling them to a deserted location. The novel ends with Samantha outspokenly asking the male members of the society for the right to vote. Jane Curry claims that Samantha on the Woman Question is a reworked version of Holley's 1885 temperance novel, Sweet Cicely. Holley self-plagiarized complete sections from her earlier work and used them in her new novel. While Samantha's trip to Washington, DC and her encounters with politicians remained precisely the same, the suffering of female characters changed remarkably.

26. Krista Cowman, "Doing Something Silly: The Uses of Humour by the Women's Social and Political Union, 1903-1914", International Review of Social History, 52.S15 (2007): 259-74 (259).

27. Linda A. Morris, “American Satire: Beginnings through Mark Twain”, A Companion to Satire: Ancient and Modern, ed. Ruben Quintero (Malden, MA: Blackwell, 2007), pp. 377-99 (391-92).

28. Winter, p. 4.

29. DuBois, p. 179. 
30. For example, one of her neighbours, Ardelia, "couldn't sign it for lack of time". She was making a quilt, which took two years to finish, "so less important things had to be put aside" (3). Likewise, Ardelia's mother could not sign the petition because of the bedspread she was making, which took three years to complete: 'She wuz quiltin' in Noah's Ark and all the animals on a turkey red quilt. I remember she wuz quiltin' the camel that day and couldn't be disturbed, so we didn't git the names" (3).

31. Carol Whitehouse, "Nineteenth-Century American Women Writers: Imagining Feminism", PhD thesis, Arizona State U, 2009, p. 4.

32. Curry, p. xviii.

33. Curry, p. xviii.

34. Curry, p. 78.

35. Corkrey, p. 103.

36. Corkrey, p. 103.

37. Curry, p. 78.

38. Frances Willard (1839-98), the founder of the Women's Christian Temperance Union, was a social reformer who also lobbied for women's suffrage.

39. Jane Addams (1860-1935) spearheaded the Settlement House Movement and created a civic awakening by founding the Hull House of Chicago. She improved the lives of many impoverished women and children, and was an active member of Theodore Roosevelt's Progressive Party.

40. Molly Eliot Seawell, "On the Absence of the Creative Faculty in Women", The Critic, 29 Nov. 1891: 292-294. Seawell (1860-1916) was a well-known southern regional writer of the time. In The Ladies' Battle, Seawell reflects her opposition to suffrage, saying: "I believe that the most important factors in the state are the wives and mothers who make of men good citizens to govern and protect the state, and I believe woman suffrage to be an unmixed evil". Molly Eliot Seawell, The Ladies' Battle (New York: Macmillan, 1911), p. 119.

41. At this point, Holley (Samantha) refers to the astronomer Maria Mitchell (1818-89), who discovered a comet with her telescope; the physicist Marie Curie (1867-1934), who pioneered research on radioactivity; the nurse Florence Nightingale (1820-1910), who "could mother and help cure an army" (33); and the novelist Harriet Beecher Stowe (1811-1916), whose story "thrilled the world and helped free a race" (34).

42. Langworthy, pp. 202-04. As contended by Langworthy, Holley was extremely shy, thus she never attended the conventions to which she was invited, yet she incorporated the material sent to her by Willard and Anthony into her novels.

43. Richard Walser, "Peattie, Elia (Maria Cahill) W.”, Dictionary of North Carolina Biography, ed. William S. Powell, vol. 5 (Chapel Hill: U of North Carolina P, 1994), p. 54; Susanne George Bloomfield, Impertinences: Selected Editorials of Elia W. Peattie, a Journalist in the Gilded Age (Lincoln: U of Nebraska P, 2005), p. 5; Susanne K. George and Susanne George Bloomfield, Kate M. Cleary: A Literary Biography with Selected Works (Lincoln: U of Nebraska P, 2000), p. 15.

44. Bloomfield, p. 73.

45. Bloomfield, p. 13.

46. Bloomfield, pp. 12, 13, 163; Georgann Eubanks, Literary Trails of the North Carolina Mountains: A Guidebook (Hillsborough, NC: Copperline, 2009), p. 400; Walser, p. 54; Susanne K. George, "Peattie, Elia”, Encyclopedia of the 
Great Plains, ed. David J. Wishart (Lincoln: U of Nebraska P, 2004), p. 334; Rebecca Borden, "Conrad as a Provocation: Elia Peattie and the Chicago Tribune, 1903-1920”, Studia Neophilologica, 85.1 (2013): 109-16 (109).

47. Elia Peattie, The Mountain Woman (New York: Doubleday and McClure, 1896); The Shape of Fear and Other Ghostly Tales (New York: Macmillan, 1898).

48. Elia Peattie, The Edge of Things (New York: Fleming H. Revell, 1903); Azalea: The Story of a Girl in the Blue Ridge Mountains (Chicago: Reilly and Critton, 1912); Annie Laurie and Azalea (Chicago: Reilly and Critton, 1913); Azalea's Silver Web (Chicago: Reilly and Critton, 1915); The Angel with a Broom (Chicago: Alderbrick, 1915).

49. Patrick Chura, Vital Contact: Downclassing Journeys in American Literature from Melville to Richard Wright (New York: Routledge, 2013), pp. 1-7.

50. The novel portrays the life of Kate Barrington, a graduate of the University of Chicago and the daughter of a tyrannical physician from Silvertree, Illinois. Disgusted with how her mother as a True Woman sacrificed her life, she leaves her father behind and moves to Chicago, experimenting with the possibilities the city could offer to a social reformer. Enmeshed within the novel's plot is a love story between Kate and her friend's cousin, Karl Wander. Karl is attracted to Kate, and during their conversations about love and marriage, they discuss the idea of a "mutual partnership" as a reworked version of companionate marriage. Karl proposes to Kate and asks her to stay with him in the mining town. Uninterested in sacrificing her independence for a man, she rejects his proposal. During a General Federation of Women's Clubs convention in southern California, Kate discovers she has been appointed head of the newly established Bureau of Children in Washington, DC, by the president of the Unites States (whom we assume to be Woodrow Wilson). During her absence from Karl, she contemplates her deep love for him. After the convention, she returns to the mining town to say farewell, but cannot suppress her feelings of love and longing. Finally able to reconcile her love with her independence, Kate finds a disappointed Karl on the precipice, or edge. They both propose a way to be happy without sacrificing the causes they deem important. They agree to maintain their relationship based on work, devotion, and equality. They decide to marry while pursuing their own agendas-Karl in his mining town and Kate in Washington, DC-with the hope they will reunite sometime in the future.

51. Jeffrey Andrew Weinstock, Scare Tactics: Supernatural Fiction by American Women (New York: Fordham UP, 2009), p. 70.

52. Sidney H. Bremer, introduction, The Precipice, by Elia W. Peattie (Champaign: U of Illinois P, 1989), pp. ix-xxvi (ix).

53. Timothy B. Spears, Chicago Dreaming: Midwesterners and the City, 1871-1919 (Chicago: U of Chicago P, 2005), p. 193.

54. Elia Peattie, “A Word with Women”, Omaha World Herald, 28 Sept. 1895: 8.

55. Borden, p. 109. Borden suggests that Peattie was inspired by the English novelist Joseph Conrad (1857-1924), who used the precipice as a metaphor for his heroine's limited choice between marriage and suicide in his novel Chance (1914), which was serialized in the United States between 1912 and 1913. In Peattie's novel, however, standing on the precipice epitomizes female freedom and determination, especially in terms of resisting Victorian notions of womanhood and embracing those of the New Woman. 
56. Chura, p. 141.

57. Sarah Jo Lock, "The People in the Neighborhood: Samaritans and Saviors in Middle-Class Women's Social Settlement Writings, 1895-1914”, PhD thesis, Texas Christian U, 2008, p. 184.

58. Chura, p. 141.

\section{Disclosure statement}

No potential conflict of interest was reported by the author.

\section{Notes on contributor}

Emine Geçgil holds a $\mathrm{PhD}$ in American Culture and Literature. She completed her doctoral studies in 2015 with a dissertation titled "By Women, For Women, About Women: Social Novels of the Progressive Era, 1900-1920". She is currently teaching in the School of English Language at Bilkent University, Ankara, Turkey, and continues to publish articles on early twentieth-century women writers. She is a member of the Executive Board of the American Studies Association of Turkey, which is affiliated with the European Association for American Studies. Her research areas include early twentieth-century women's fiction and women's reform movements.

\section{ORCID}

Emine Geçgil (D) http://orcid.org/0000-0002-6521-7513 